\title{
Direct Object Double Marking in Celtic and South Slavic Languages - Preliminary Remarks
}

\section{ELENA PARINA}

\section{Introduction}

The phenomenon of direct object double marking in Old and Middle Irish was described by Ina Lucht in her paper 'Doppelte Markierung des Akkusativs beim Transitivum im Altirischen' (Lucht 1994). ${ }^{1}$ She analyses constructions such as (1) below as examples of "after-thought topic shift":

(1) Old Irish (SMMD $\S 9.8)$

$$
\begin{array}{llllll}
n i- & \boldsymbol{s} & \text {-toirchi } & \text { in } & \text { muicc } & \text { fon indas sin } \\
& \text { 3Sgf } & \mathrm{V} & \text { art:AccSg } & \text { pig:AccSg } &
\end{array}
$$

'You will not get the pig in that way'.

The NPs doubled by object clitic are usually characterised by definiteness and/or giveness (Lucht 1994: 89-90). The author records a Middle Irish tendency for co-occurence of object clitic and independent pronoun, impossible in Old Irish (ibid. 112).

(2) Middle Irish (LU 8877)

$$
\begin{aligned}
& \text { no-s- } \quad \text { curat } 7 \text { no- s- traethat inna geniti hé } \\
& \text { Obj3Sgm V Obj3Sgm V 3Sgm }
\end{aligned}
$$

'The spirits were beating and overpowering him'

In the conclusion of her paper she asserts that the construction analysed is possible in all languages that possess object clitics and refers especially to colloquial French, the Balkan languages, and Middle Welsh.

\section{Towards a classification of the categories of the phenomenon of double marking in Celtic and Slavic}

Is the construction in the languages referred to above really the same? In how far can we consider examples $(1,2)$ and $(3,4,5)$ below as the same phenomenon?

\footnotetext{
The author acknowledges the assistance of Dr. A. Y. Rusakov and Dr. A. B. Borisova (St. Petersburg) in the preparation of this paper.
} 
DIRECT OBJECT DOUBLE MARKING IN CELTIC AND SOUTH SLAVIC LANGUAGES PRELIMINARY REMARKS

(3) French

Je veux la voir, elle

'I want to see her'

(4) Bulgarian (Lopashov 1978: 28)
A познаваше го
mя $u$ него
хубаве
V 3SgmAcc:clitic
$3 \mathrm{SgmAcc}$

'And she knew also him well'

(5) Middle Welsh (Pedeir Keinc y Mabinogi = PKM: 87.2-3)

$\begin{array}{llllll}\text { Pwy bynnac } & a & \boldsymbol{m} & \text { metrei } & \boldsymbol{i} & \text { yuelly... } \\ & & \text { Obj1Sg } & \mathrm{V} & 1 \mathrm{Sg} & \end{array}$

'Whoever should smite me so...' (translation after Jones \& Jones 1949: 70).

What all these examples have in common is the possibility of the presence of an NP or a strong pronoun and an object clitic in the same sentence. We think the following oppositions to be essential.

1. The NP can be either separated as an R-dislocation or L-dislocation, standing in a neutral case and separated from the clitic-containing clause by a pause, or be case-marked as object and stand within the same clause as the clitic. ${ }^{2}$

2. The clitic can be either anaphoric or cataphoric, and a language may allow either both constructions or only one of them.

3. The type of the NP doubled by the object clitic may vary. First, the language may or may not allow the use of a strong pronoun in this position. Secondly, referential properties of the NP may differ. ${ }^{3}$

4. The extent of grammaticalisation of such constructions is essential - whereas in some languages it is a topic-marking device, in others it is a syntactic device which would help to identify syntactic roles within the sentence (the extreme point of such grammaticalisation is verb conjugation with obligatory object agreement).

\footnotetext{
One should bear in mind that in languages lacking case-marking this distinction is difficult to draw. In dealing with written languages where nothing is known about the intonation, these constructions are almost indistinguishable

3 There are, however, certain universal tendencies which are discussed later.
} 
5. These anaphoric and cataphoric constructions may be characteristic of direct object double marking only. Such an option might also be possible for NPs with different syntactic functions: subject, indirect object, possessor etc.

The description of direct object double marking in Celtic and Slavic languages according to this classification would create a map of crosslinguistic variation of this phenomenon, so that we could better understand the role several types of these constructions play in topic marking, the way object agreement in verbs develops etc. Of course, at a later stage of research, further languages of the world possessing this construction should also be taken into consideration (in the first instance, the Romance languages, on the material of which the reprise construction was first studied).

This phenomenon has been analysed from several points of view. Clitic doubling in Balkan languages has been studied extensively in works of generativists, as the co-occurrence of clitics with an overt phrase constitutes a problem for the assumption that all clitic constructions come about by means of movement (van Rijmsdijk 1999: 7ff.). Some generativists claim that clitic doubling and right-dislocation are the same phenomenon with the difference at the logical formlevel(Kayne 1994), after(Anagnostopoulou 1999: 791 fn.7). From a functional point of view the phenomena described were analyzed by T. Givón as marked-topic constructions (Givón 1990: 752-762).

It should be added that the description of this phenomenon in languages should follow "usage description", with special attention being given to frequency, obligatoriness or optionality of several types of the construction, rather than a mere "system description" which only marks the presence or absence of the construction (see the distinction drawn, e.g. in Sobolev (2005:183)).

It should be clear from what has been said that this type of study can hardly be achieved by one scholar working alone but should be conducted by a team of specialists in Celtic and Balkan languages in order to identify and understand variations and common features of the construction. 
DIRECT OBJECT DOUBLE MARKING IN CELTIC AND SOUTH SLAVIC LANGUAGES PRELIMINARY REMARKS.

\section{Direct object double marking in Middle Welsh in comparison to Bulgarian and Macedonian}

What we would like to present now is our analysis of one of the languages mentioned at the end of I. Lucht's paper, Middle Welsh. The focus of our attention will be the text Pedeir Keinc y Mabinogi (PKM = Williams 1951). As our aim is to compare the usage of the direct object double marking in Slavic and Celtic languages, we shall add some preliminary remarks on Bulgarian and Macedonian.

In PKM the following types of concurrence of a clitic with an overt NP are recorded:

(a) $\mathrm{O}(\mathrm{N})$ - L-dislocated - traditionally called Nominativus pendens in Indo-European linguistics, this construction has drawn much attention since it is believed to be a starting point for the Welsh abnormal sentence (Mac Cana 1973).

(b) (6) Middle Welsh (PKM: 8.15-16)

$$
\begin{array}{lcc}
a^{\prime} \boldsymbol{r} & \text { arglwydiaeth a gaussam ninheu y ulwydyn honno, } & \text { nys attygy y gennym } \\
\text { and=art. } & \text { rule } \mathrm{f} . & 3 \mathrm{Sgf} \mathrm{V}
\end{array}
$$

'And the rule we have had that year thou wilt not withhold [it] from us'.

This construction is not very often found in narrative prose, we find only two examples in PKM, all with negation (a pragmatic explanation of this fact is given by G. Isaac (1994: 60)). Note that the same construction, also with negation, is found in Old Welsh:

(7) Old Welsh (Surexit Memorandum)

$$
\begin{array}{llll}
\text { refiat } & \text { uetic } & \text { nis } & \text { inn tutbulc hai cenetl in ois oisou } \\
\text { title } & \text { neg=Obj3Sgm } \mathrm{V}
\end{array}
$$

'Tudfwlch and his people will require no title ever afterwards' (translation after Isaac 1994: 12). ${ }^{4}$

Though quite rare in narratives, this construction is more widespread in functional prose, for example law texts, where the fronted NP plays the role of a head.

In PKM there is also one example of independent pronoun fronting:

(8) Middle Welsh (PKM: 74.16)

\footnotetext{
$\overline{4}$ For a different interpretation proposed by T. Arwyn Watkins see Jenkins \& Owen 1984: 106-107.
} 


$$
\begin{aligned}
& \text { A thitheu," heb ef, "mi a'th gymeraf ynwreic im } \\
& \text { 2Sgconj } \mathrm{RP}=\mathrm{Obj} 2 \mathrm{Sg} \mathrm{V}
\end{aligned}
$$

'As for thee, he said, I will take thee to wife'.

We should add one point here: Welsh has no declension, therefore it is difficult to draw a merger between L-dislocation and NP fronting within the clause boundary. It is questioned therefore whether these constructions are fundamentally the same: whereas E. Poppe claims there is a functional distinction between these constructions (Poppe 1991: 196-97), G. Isaac claims that left-dislocation and topicalisation without a resumptive pronoun are "formal variants, in complementary distribution, of the same functional strategy" (Isaac 1994: 60ff.).

Now we turn to the Welsh parallels of the sentences described by I. Lucht. As Welsh lacks case-marking it is very difficult to distinguish between a dislocation with neutralised case and a post-verbal placing of a case-marked direct object with an NP preceding it. ${ }^{5}$

Examples with anticipated NP are quite rare in Middle Welsh. None are found in PKM. The example quoted by I. Lucht comes from another text, Breudwyt Ronabwy:

(9) Middle Welsh (Melville Richards 1948: 4.29)

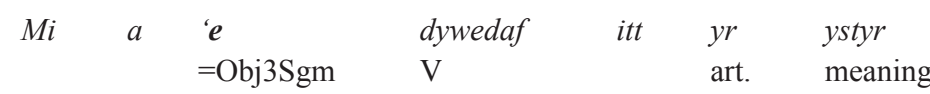

'I will tell it to you, the meaning';

Further examples are gathered in Strachan (1909: 36) and Simon Evans (1964: 56-57). It is interesting to note that not all of the anticipated objects are definite, cf. the following sentence from the Gododdin:

(10) Middle Welsh (Canu Aneirin 210, after Isaac 1996)

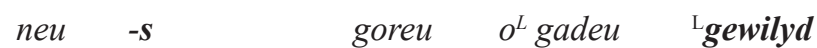

$$
\begin{aligned}
& =\text { Obj3Sgm } \mathrm{V} \quad \text { disgrace }
\end{aligned}
$$

'he made [it] a disgrace of armies'.

It is to be noted that difficulties often arise in distinguishing these constructions, see Givón 1991: 761 . 
This is a remarkable point, because typologically definite objects are more often doubled by a pronoun clitic or affix than indefinite ones. ${ }^{6}$ All Balkan languages support this universal, though the referential status of doubled NPs and the obligatoriness of the reprise varies from language to language (Dimitrova-Vulchanova, Hellan 1999: 509 fn. 13). In Bulgarian the doubled NP has to be specific, "which signifies that the expression in question is used about an entity or matter which is being identified by the speaker as a particular entity", a feature distinct from definiteness (Dimitrova-Vulchanova \& Hellan 1999: 484). In Macedonian double marking of direct object is more widespread than in Bulgarian (whereas in a literary Bulgarian text only $10 \%$ of transitive verbs have double marked direct objects, in Macedonian this figure reaches 50\% (Assenova 1989: 84)). Specific direct and indirect objects marked by the definite article and also pronominal forms necessarily trigger clitic doubling (DimitrovaVulchanova \& Hellan 1999: 509 fn. 14), this double marking occurs irrespective of the position of the NP to the verb (Lopashov 1978: 38).

In contrast to Old Irish, where the co-occurence of pronominal clitic and independent pronoun is impossible, both Balkan Slavic languages and Middle Welsh make wide use of such a construction. It was noted that in Bulgarian and Macedonian pronominal reprise is more frequent with full form pronouns (Lopashov 1978: 32). According to P. Assenova, clitic doubling in Bulgarian started out as the doubling of topicalized pronominal objects (Dimitrova-Vulchanova \& Hellan 1999: 509 fn. 17; Assenova 1989: 80). The semantics of this reprise is described in different ways. Some scholars claim the reprise has often a semantics of contrast or emphasis (de Bray 1951: 206):

\footnotetext{
6 Cf. I. Lucht's results for Old Irish summarised at the beginning of our paper. See Givón (1984: 372) for an example from Swahili on the primacy of definite over indefinite in grammatical agreement.
} 
(11) Bulgarian (de Bray 1951: 206)

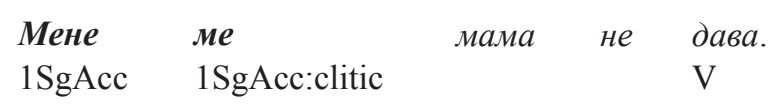

'Mother does not give $m e$ '.

Others assert that, in the case of logical stress, personal pronouns are not doubled and only the full form is used:

(12) Bulgarian (Assenova 1989: 290)
a. Hezo
изключиха от училище
3SgmAcc
$\mathrm{V}$

'It was him who was expelled from college';

vs. neutral

$\begin{array}{llll}\text { b. Него } & \text { го } & \text { изключиха от училище } \\ & \text { 3SgmAcc } & \text { 3SgmAcc:clitic } & \mathrm{V}\end{array}$

'He was expelled from college'.

The same is true for Macedonian: while some authors report obligatoriness of co-occurence of clitic and full form pronouns (Lopashov 1978: 32), others describe it as a means of emphasis (Lunt 1952: 38; IllichSvitych 1963: 568).

(13) Macedonian (Lopashov 1978: 15)

$\begin{array}{lllll}\text { Мене } & \text { ме } & \text { остава, него } & \text { го } & \text { зема } \\ \text { 1SgAcc } & \text { 1SgAcc:clitic } \mathrm{V} & \text { 3SgmAcc } & \text { 3SgmAcc:clitic } & \mathrm{V}\end{array}$

'He left me, he took him'.

(14) Macedonian (Lopashov 1978: 32)

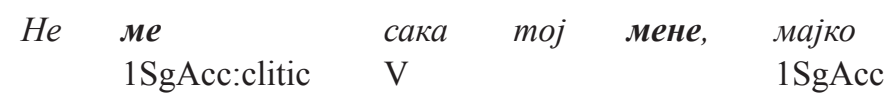

'He doesn't love me, mother'.

The use of terms like 'emphasis', 'logical accent', as they are commonly used, illustrates the vagueness of the description and does not constitute a 
real attempt to describe the semantics of the construction. ${ }^{7}$ We shall see the same obstacle in our analysis of Middle Welsh.

Before we start analysing the tendencies of pronoun reprise in Middle Welsh, like that in example (5), it must be noted that Welsh full form pronouns have a different status to the full form pronouns in South Slavic languages. The Welsh pronouns found in this construction have the same form as pronouns used independently (the discrepancies in 1-2 Sg. are described with a compact set of rules):

(15) Middle Welsh (PKM: 78.4, 26.23)

$\begin{array}{lllll}\text { a. } & \text { ef } & a & \text { glywei } & \text { diaspat } \\ & 3 \mathrm{Sgm} & \mathrm{P} & \mathrm{V} & \text { cry }\end{array}$

'He heard a cry';

$\begin{array}{lllll}\text { b. } \quad y \text { wreic } & a & \text { e } & \text { magwys } & \text { ef } \\ & & \text { Obj3sgm } & \mathrm{V} & 3 \text { Sgm }\end{array}$

'The lady that nursed him'.

They are classified as affixed and distinguished from independent pronouns by John Morris Jones (1913: 274), a classification adopted also by D. Simon Evans (1964: 57) in his Grammar of Middle Welsh, whereas T. Arwyn Watkins brings both the dependent affixed and independent pronouns of J. Morris-Jones into one class labelled "General pronouns" (Watkins 1977: 157; Watkins 1993: 316). They can support (or "echo", using a term proposed by I. Roberts and U. Shlonsky (Roberts \& Shlonsky 1996: 181ff.)) not only object proclitics, but also possessive proclitics (16a), verbal flexions, denoting subject (16b) and prepositional flexions, denoting prepositional object (16c).

(16) Middle Welsh (PKM: 64.3-4, 75.20, 9.8)

a. Wy gwreic $\boldsymbol{i} \quad y w h i$ my $\quad 1 \mathrm{Sg}$

'She is my wife';

b. Ymabhagen a $\begin{array}{ll}\text { gymeraf } \\ \text { take-prs1Sg }\end{array} \quad \begin{aligned} & \boldsymbol{i} \\ & 1 \mathrm{Sg}\end{aligned}$

'The boy however I will take';

Cf. A. Wierzbicka (1986: 290): "One could say, of course, that the function of the Italian reduplication is that of 'emphasis' - as people often do speaking of devices whose exact force they are unable to state". 


$$
\begin{array}{llcl}
\text { c. Nytoes } & \begin{array}{l}
\text { arnaf } \\
\text { on-1Sg }
\end{array} & \boldsymbol{i} & \text { ouyn cael kymriw }
\end{array}
$$

'I do not fear to receive wounds'.

They depend on clitics or agreement affixes in that their use without them is ungrammatical: e.g. *gwreic $i$ 'my wife' or *ar $i$ 'on me'. ${ }^{8}$

This construction of pronominal reprise has drawn much attention from Welsh scholars (an excellent summary of this discussion is given in (Rowlands 1981: 424ff)), particularly because, as T. Arwyn Watkins wrote, the difference in the usage of affixed pronouns reflects strikingly the gap between spoken and literary Modern Welsh (Watkins 1977-8: 349). It is generally admitted that in spoken Welsh affixed pronouns are used very often, whereas in literary Welsh they are used much less frequently. In spoken Welsh there is also an opposition between stressed (or better described in terms of vowel lengthening) affixed pronouns conveying emphasis and non-stressed affixed pronouns without vowel lengthening, which do not convey any emphasis. ${ }^{9}$ Mac Cana (1975-6: 323) noticed that the discrepancy between the spoken and literary languages might go back to Middle Welsh and noted a tendency for a more frequent usage of affixed pronouns in PKM dialogues.

Interestingly, the usage of pronominal reprise as a feature of oral speech is instanced for Balkan languages too, especially for Bulgarian (Lopashov 1978: 37, 122; Assenova 1989: 83).

Whereas in Modern Welsh it might be possible to take the stress as a guideline for distinguishing between emphasising and non-emphasising uses of echo pronouns, in Middle Welsh we know next to nothing about it (instances of reduction of pronouns after flexions they echo may serve as an indication of the lack of stress, cf. ny chawni 'we shall not have' from $n y^{\mathrm{S}}$ chawn ni (PKM: 70.04-5), but spellings like that occur inconsistently). And as the notions of "emphasis" and "logical stress" are quite vague, we are unlikely to understand the function of an echo pronoun in each separate case. But this is not an obstacle to understand the general tendencies of the usage of such constructions in Middle Welsh. To achieve this goal we have

\footnotetext{
In colloquial Modern Welsh the forms like gwreic $f i$ are possible, though ar $f i$ is not acceptable.

9 Here I am indebted to Dr. Iwan Wmffre for his insights regarding the use of dependent pronouns in literary and spoken Welsh.
} 
DIRECT OBJECT DOUBLE MARKING IN CELTIC AND SOUTH SLAVIC LANGUAGES PRELIMINARY REMARKS.

analysed all the examples of object clitics, possessive clitics and personal forms of conjugated prepositions in PKM. The statistics are as follows:

Table 1. Echo pronouns supporting object clitics in PKM

\begin{tabular}{lllllll}
\multicolumn{3}{c}{ Direct speech } & \multicolumn{3}{c}{ Indirect speech } \\
\multicolumn{3}{c}{$1-2$ person } & & 3 person & \multicolumn{3}{c}{3 person } \\
& - & + & - & + & - & + \\
$\#$ & 11 & 6 & 52 & 4 & 18 & 2 \\
$\%$ & 64.7 & 35.3 & 92.8 & 7.2 & 90 & 10
\end{tabular}

Affixed pronouns are more frequently used in 1-2 persons, also with possessive pronouns and personal forms of the conjugated prepositions.

Table 2. Echo pronouns supporting possessive clitics denoting possessor in PKM

\begin{tabular}{lllllll}
\multicolumn{3}{c}{$\begin{array}{l}\text { Direct speech } \\
\text { 1-2 person }\end{array}$} & \multicolumn{3}{c}{ 3 person } & \multicolumn{3}{c}{ Indirect speech } \\
& - & + & - & + & - & + \\
$\#$ & 147 & 58 & 64 & 12 & 271 & 36 \\
$\%$ & 71.8 & 28.2 & 84.2 & 15.8 & 88.3 & 11.7
\end{tabular}

Table 3. Echo pronouns supporting personal forms of conjugated prepositions in PKM

\begin{tabular}{lllllll}
\multicolumn{3}{c}{ Direct speech } & \multicolumn{3}{c}{} & \multicolumn{3}{c}{ Indirect speech } \\
& $1-2$ person & & 3 person & \multicolumn{3}{c}{3 person } \\
& - & + & - & + & - & + \\
$\#$ & 102 & 92 & 68 & 18 & 194 & 49 \\
$\%$ & 52.6 & 47.4 & 79.1 & 20.9 & 79.9 & 20.1
\end{tabular}

Thus we see that the contrast lies not between oral vs. written registers, but between the first and the second person, on the one hand, and the third person, on the other.

If we glance at the history of Welsh, we can see the same phenomenon in other texts. Though it may not be considered as statistically reliable evidence, the only example of an echo pronoun supporting an object clitic in Gododdin is the first person plural:

(17) Middle Welsh (Canu Aneirin 930, after Isaac 1996: 229)

$$
\begin{array}{llll}
\text { an } & \text { gelwir } & \boldsymbol{n y} & \text { faw glaer fwyre } \\
\text { Obj1 } \mathrm{Pl} & \mathrm{V} & 1 \mathrm{Pl} &
\end{array}
$$

'We are called bright of fame'. 
In the Sir Ifor Williams' (1935) edition of Canu Llywarch Hen there are several instances of pronouns marked as later insertions (this has been already noticed in Mac Cana 1975-6: 321). ${ }^{10}$ All those pronouns are first person and second person sg. In Culhwch ac Olwen (Bromwich \& Evans 1992), an earlier text than those in PKM, echo pronouns are used less frequently than in PKM, but first person and second person pronouns are used more frequently than the third person. In Buched Dewi (Simon Evans 1988) we can see the transition between the PKM state of affairs and modern writing. In the text first and second person pronouns are echoed more frequently than the third person, but in direct speech third person pronouns are echoed more often than in narrative. In the writings of Kate Roberts we were not able to find the opposition between the first person and the second person, on the one hand, and the third person, on the other, in the use of echo pronouns.

\section{Conclusion}

At the beginning of our paper we claimed that the usage of constructions analysed may be conditioned grammatically or pragmatically. This double marking is claimed as a grammatical device in Bulgarian and Macedonian which helps to identify syntactic function (Zychun 1963: 111). They are used "for clearness sake" (Lopashov 1978: 92). The same is claimed to be one of the main functions of echo pronouns in Modern Welsh - it is asserted that it helps to distinguish between masculine and feminine in 3 sg (King 1993: 81). Following T. Givón, Ina Lucht showed that in Old Irish the direct object double marking is an afterthought device, used when the speaker, having first named the referent with an anaphoric pronoun, decides later that the referent is not so accessible and so is re-coded as a full NP (Lucht 1994: 91; Givón 1990: 761). This phenomenon is thus dictated in many languages by the hearer's requirements.

For Middle Welsh, where we might expect the same tendency, we can propose that the use of echo pronouns reflects another feature of human language, i.e. the distinction between the locutors and non-locutors (see Nichols 1988: 580; Kibrik 2004: 150-1; Bhat 2004 : 132ff.; Siewierska 2004: $5 \mathrm{ff}$.). The idea of this distinction has a long history both in theoretical and historical linguistics: E. Benveniste noted that the third person had

\footnotetext{
${ }^{10}$ It has to be mentioned that from now on we shall not only focus on the direct object double marking, but shall also turn our attention to the affixed pronouns in several syntactic positions.
} 
DIRECT OBJECT DOUBLE MARKING IN CELTIC AND SOUTH SLAVIC LANGUAGES PRELIMINARY REMARKS

exceptional status (Benveniste 1966: 255). There are no common IndoEuropean personal pronouns of the third person and O. Szemerényi writes that "das Pronomen der 3. Person ... ist natürlich nicht ein Personalpronomen, sondern ein Anaphoricum” (Szemerényi 1989: 224).

Thus, we have another point of cross-linguistic variation, which should be added to the guidelines of classification, proposed at the beginning of our paper - does a language differentiate between the use of pronominal reprise in the first and the second persons, on the one hand, and the third person, on the other?

Our paper should be considered as a preliminary analysis of the phenomenon of pronominal reprise in Celtic and Slavic, contributing to its better understanding in the languages of the world.

Institute of Linguistics

Russian Academy of Sciences, Moscow

\author{
SUMMARY: \\ ЕЛЕНА ПАРИНА
}

\author{
ДВОЙНОЕ МАРКИРОВАНИЕ ПРЯМОГО ДОПОЛНЕНИЯ В \\ КЕЛЬТСКИХ И ЮЖНОСЛАВЯНСКИХ ЯЗЫКАХ - \\ ПРЕДВАРИТЕЛЬНЫЕ ЗАМЕЧАНИЯ
}

\begin{abstract}
В ОСТРОВНЫХ КЕЛЬТСКИХ ЯЗЫКАХ, ТАКЖЕ КАК И В ЮЖНОСЛАВЯНСКИХ ЯЗЫКАХ, ВХОДЯЩИХ В БАЛКАНСКИЙ ЯЗЫКОВОЙ СОЮЗ, РАСПРОСТРАНЕНО ДВОЙНОЕ МАР КИР ОВАНИЕ ПР ЯМОГО ДОПОЛНЕНИЯ. В НАШЕЙ РАБОТЕ МЫ ПРЕДЛАГАЕМ СХЕМУ ОПИСАНИЯ, БЛАГОДАР Я КОТОР ОЙ ЭТО ЯВЛЕНИЕ МОЖЕТ БЫТЬ ОПИСАНО ЕДИНООБ Р АЗНО В ЯЗЫКАХ Р АЗЛИЧНЫХ ГРУПП, И ПР ИМЕНЯЕМ ЕЕ К СР ЕДНЕВАЛЛИЙСКОМУ МАТЕР ИАЛУ. НАИБОЛЕЕ РАСПРОСТРАНЕННЫМ ТИПОМ ДВОЙНОГО МАРКИРОВАНИЯ ПР ЯМОГО ОБЪЕКТА В СРЕДНЕВАЛЛИЙСКОМ ЯЗЫКЕ ЯВЛЯЕТСЯ ОДНОВР ЕМЕННОЕ УПОТРЕБЛЕНИЕ АККУЗАТИВНЫХ КЛИТИК И РЕПРИЗНЫХ МЕСТОИМЕНИЙ, ПРИЧЕМ ЭТА КОНСТРУКЦИЯ ВСТРЕЧАЕТСЯ ГОРАЗДО ЧАЩЕ В 1-2 ЛИЦЕ, ЧЕМ В 3. ОПИСАНИЕ ДВОЙНОГО МАР КИР ОВАНИЯ ПР ЯМОГО ОБЪЕКТА В КЕЛЬТСКИХ И ЮЖНОСЛАВЯНСКИХ ЯЗЫКАХ ПО ПРЕДЛОЖЕННОЙ СХЕМЕ ОБОГАТИТ ПРЕДСТАВЛЕНИЯ О ВОЗМОЖНОМ МЕЖЪЯЗЫКОВОМ ВАР ЬИР ОВАНИИ ЭТОГО ЯВЛЕНИЯ.
\end{abstract}

